v jednotlivých oblastech bádání; míry, v níž poskytuje prostředky $\mathrm{k}$ reorientaci a reintegraci sociologie rozdrobené do velkého množství specializací a podoborů; oprávněnosti Eliasovy kritiky ústupu sociologie do současnosti v kontextu soudobé sociologie; potenciálu, který poskytuje koncepce figurací pro současný výzkum; slučitelnosti Eliasova pojetí s výzvami k prosazování „veřejné sociologie“ a s explicitně politickou a stranicky zaměřenou sociologií. Tematické okruhy konference se zaměřily na problematiku procesu civilizace, decivilizace, válek a teroru; koncept figurací v rámci debat o struktuře a jednání; sociologii vědění a problém metodologie; otázky sportu, volného času, konzumu, nerovnosti, etnicity, exkluze a migrace.

Klíčové postavení v rámci konference měl referát Possible futures; propositions and questions, který přednesl Johan (Joop) Goudsblom, jenž je jako dlouhodobý propagátor Eliasovy sociologie znám především díky knize Fire and Civilization (1992). Goudsblom shrnul obsah svého vystoupení do osmi základních tezí s následujícím obsahem: 1. Lidé nejsou a nikdy nebudou schopni předvídat budoucnost. 2. Lidské bytosti, stejně jako jiné formy života, sestávají ze specifické kombinace hmoty, energie a informací, a to bude platit i nadále. 3. Převládajícím trendem lidské historie až do současnosti je expanze lidského světa, ,antroposféry“, přičemž je otázkou, zda tento trend bude nadále pokračovat ve zrychlujícím tempu. 4. Civilizace (stejně jako decivilizace) je procesem kolektivního učení, který se objevil v expandující antroposféře. 5. Lidé na raných stupních svého vývoje objevili, že určité zvláštní formy hmoty mohou sloužit jako palivo - hlavní zdroj energie, jaký dnes známe. 6. Základním trendem v užívání energie je v naší době elektrifikace; proto je důležité zkoumat spojení mezi elektrifikací a civilizací. 7. V možné budoucnosti by mohla být potřeba energie zajištována celosvětovou energetickou sítí (World Wide Web of Energy), což by však vyžadovalo vyšší standard civilizace a formování státu, než je ten, jehož bylo doposud dosaženo. 8. Předzvěstí takovéto možné budoucnosti je současný celosvětový systém měření času.

Zajímavých a podnětných příspěvků zaznělo na konferenci velké množství. Zmiňme z nich jenom některé. Stephen Mennell referoval o koncepčních problémech spojených s editováním sebraných spisů. Marc Joly analyzoval vliv německé filozofie a sociologie na Eliasovu odbornou orientaci. Norman Gabriel a Lars Bo Kaspersen se zamýšleli nad rolí náboženství v př́stupu k civilizačnímu procesu. Richard Kilminster konfrontoval eliasovské myšlení s Marxem. Dennis Smith se zabýval vzájemným srovnáním životních osudů André Bretona a Norberta Eliase. Abram de Swaan se zaměřl na koncept genocidy a anihilace. Cas Wouters hovořil o vztahu evoluce a informalizačního procesu. François Dépelteau se orientoval na problém sociální zkušenosti a vědění. Barbora Misztal kritizovala Eliase za nedostatečnou reflexi procesu formování občanské společnost. Robert van Krieken provedl komparaci dvorské společnosti s moderní společností celebrit. Gordon Fyfe postavil figuraci etablovaných a outsiderů do vztahu s otázkou sociogeneze muzeí. A autor této zprávy přednesl referát o pojetí figurace jako teoretického nástroje, jehož úkolem má být překlenout dualismus individua a společnosti.

Celkově lze konstatovat, že konference konaná v červnu 2014 v Leicesteru byla vynikající připomínkou Eliasova díla, a zároveň i stvrzením jeho stálé inspirativní hodnoty. Pro všechny účastníky to byla mimořádně př́ijemná společenská událost, která přispěla k navázání a prohloubení řady odborných kontaktů. Pro obor historické sociologie je to zároveň i doklad toho, že perspektiva, kterou se snaží uplatňovat při zkoumání dlouhodobých společenských procesů, má v kontextu soudobé světové sociologie své významné postavení.

Jiři Šubrt

\section{Konference Fenomén hospodářské krize $v$ českých zemích / střední Evropě 19. a 20. století}

Ve dnech 18. a 19. ř́ijna 2013 se v prostorách Právnické fakulty Univerzity Karlovy a Vysoké školy ekonomické v Praze uskutečnila mezinárodní vědecká konference s názvem Fenomén hospodárské krize $v$ českých zemích / střední 
Evropě 19. a 20. století a podtitulem Promèna cyklického vývoje ekonomiky v procesu gradujicí globalizace. Úvodními slovy pozdravili účastníky konference prorektoři Univerzity Karlovy a Vysoké školy ekonomické prof. Ivan Jakubec a prof. Jindřich Soukup, poté už mohlo zaznít na několik desítek zajímavých příspěvků, které $\mathrm{z}$ různých úhlů pohledu zkoumaly fenomén hospodářské krize.

První den konference proběhl vstupní a teoretický blok, v rámci něhož byly jednotlivé referáty zaměřeny jednak na krizi jakožto ekonomický a společenský fenomén $\mathrm{v}$ teoretickém kontextu (Pavel Syrůček: Krize současné a minulé prizmatem dlouhých vln; Jana Geršlová: Podnikání a jeho proměny v obdobi krize; Jan Vorlíček: Krize jako teoretický problém), jednak na českou percepci fenoménu hospodářské krize (Eduard Kubů: Krize v českých zemích a Československu jako historiografický problém; Jaroslav Krameš: Problém hospodárské krize v českém ekonomickém myšlení; Ilona Bažantová: Čeští Keynesovci a jejich porozumění hospodářské krizi).

Druhým dnem se konference posunula do své hlavní ćásti. Jednotlivá vystoupení účastníků byla rozdělena do dvou sekcí, sekce tržní ekonomiky a sekce direktivně rízené ekonomiky, transformace a ekonomické současnosti. Referáty byly obecně zaměřeny na fenomén hospodářské krize a jeho percepci různými vědeckými obory. Vyzdvihnout lze především referát Jiřího Buriánka Moderní krize v sociologických výzkumech, v němž autor interpretoval proměny vnímání fenoménu krize ve výzkumech veřejného mínění, dále se v něm zaměřil na proměny vnímání korupce, vlastní životní úrovně či celkového stavu společnosti. Z referátu vyplynula nejen prokazatelná souvztažnost mezi proměnami vnímání krize a hospodářského cyklu, tedy že $\mathrm{v}$ časech krize lidé vnímají situaci pesimističtěji, než jaká skutečně je, a naopak. Nadto ovšem zazněl více varující nepřehlédnutelný dlouhodobý trend nárůstu negativních odpovědí a vnímání korupce jako systémového problému. Zuzana Džbánková přednesla príspěvek s názvem Obraz krize v podnikatelské mentalitě a etice, v němž se pokusila ukázat, že podnikatelská etika je v českém prostoru stále víceméně v plenkách, zejména $\mathrm{z}$ důvodu, že drtivá většina manažerů dotazovaných podniků se $s$ autorkou odmítla bavit, prrípadně odpovídala naučenými frázemi nebo rovnou přiznala nezájem o tuto tematiku. Na druhé straně je však ze srovnání dvou autorčiných výzkumů zjevné, že sledovaný trend se v posledních deseti letech přeci jen pozitivně vyvíjí. V zásadě jednoznačným závěrem referátu pak bylo, že v krizových dobách je výrazně dominantním postupem upřednostnění momentální ekonomické výhody, a to i za cenu porušení etických pravidel.

Početně silně zastoupeny byly také prríspěvky týkající se vlivu celé řady hospodářských krizí před rokem 1989 na různá odvětví ekonomiky či různé společenské jevy (Jiří Dobrylovský: Hospodárská krize 1847-1848; Petr Popelka: Dopad hospodárské krize 70. let 19. století na rakousko-uherskéželezniční společnosti; Jan Hájek: Velká deprese a vývoj peněžnictví; Vojtěch Pojar: Hospodárská krize - formativní činitel kartelizace pojištovnictví na území Předlitavska; Jiří Pešek: Souvztažnost velké deprese a procesu urbanizace; Lukáš Fasora: „Nechte si svou organizaci, dejte nám chleba a brambory!"Drahotní krize jako základ ultralevicové revolty $v$ Rakousku 1907-1914; Torsten Lorenz: Dynamika vývoje družstevnictví ve střední Evropě; Jiři Šouša jr.: Obraz hospodářské krize $v$ legislativní perspektivě Předlitavska, Československa, České republiky). V rámci této skupiny se několik referátů zaměřilo na velkou hospodářrskou krizi mezi světovými válkami (Aleš Zářický: Velká deprese; Jakub Kunert: ČNB v době Světové hospodářské krize a dvě př́padové studie, které budou zmíněny později). Autora zprávy nejvíce zaujal referát Jakuba Rákosníka Československý stát a problematika nezaměstnanosti v období Světové hospodářské krize, ve kterém se přednášející zamýšlel nad srovnáním fenoménu nezaměstnanosti v době krize 30 . let 20. století a dnes. Upozornil na řadu metodologických problémů, které komplikují už pouhé zjištění skutečného počtu nezaměstnaných, nebot za velké krize byl v ČSR za nezaměstnaného považován pouze ten, kdo a) se přihlásil na zprostředkovatelně; b) byl předtím zaměstnán (tedy napr. nikoli živnostníci a absolventi škol); c) byl členem odborů a platil si prríspěvky; d) neodhlásil se ze zprostř̌edkování, nebo mu neskončila podpůrčí doba. Jako další srovnal několik dobových prrístupů k řešení problému nezaměstnanosti a nakonec shrnul hlavní 
důvody odlišných dopadů ztráty zaměstnání na životní situaci před 80 lety a dnes, tedy že žijeme obecně v době dostatku, kdy lidé mají obvykle určité finanční rezervy, navíc se výrazně změnila struktura výdajů - „je více možností jak a z čeho se uskromnit“ - a konečně jsou dnes také pravidlem dvoupřímové domácnosti.

Několik prríspěvků se zabývalo ekonomickým a sociálním vývojem po roce 1989 (Monika Palatková: Změny ve spotřebním chování obyvatel České republiky v turismu po roce 1989; Jan Slavíček: Dynamika vývoje spotřebního družstevnictví ve vazbě na vývoj hospodárského cyklu) a řada dalších se specificky věnovala různým aspektům finanční krize po roce 2008 (Petr Hájek: Finanční nákaza 2007/2008 a její cesta do ČR; Michal Brožka: Finanční trh ČR ve víru finanční krize; Tomáš Pavelka: Dopad nedávné ekonomické recese na státy střední Evropy). Někteří účastníci konference se zaměřili také na vliv hospodářských krizí na zahraniční politiku (Eduard Kubů - Jiř́ Šouša: Československo na konferenci Společnosti národu o problematice hospodárské krize 1927; Žarko Lazarević: Hospodářská krize a jihoslovanské investice českého kapitálu; Adéla Junová-Macková: Krize - impuls k rozvoji obchodu s Blizkým a Středním východem). Další probíraný okruh se týkal vlivu krizí na růst regulačních opatření (např. Barbora Štolleová: Agrární krize a státní intervencionismus meziválečné ČSR). Tři př́spěvky byly věnovány fenoménu kartelizace (již zmiňovaný prríspěvek Vojtěcha Pojara, dále pak Tomáš Gecko: Kartelizace cementářského průmyslu jako výraz snahy prekonávání krize a Kateřina Rozinková: Kartelizace trhu piva v českých zemích).

Velmi zajímavé byly referáty postihující problematiku hospodářských krizí v centrálně plánované ekonomice (Drahomír Jančík: Krize v systému centrálnè plánované ekonomiky - kolaps československé 3. pètiletky; Jaroslav Láník: Československá zbrojní krize 50. let). Drahomír Jančík ve svém příspěvku odhalil příčiny zhroucení třetího pětiletého plánu v ČSR v roce 1963, které vyplývaly především z přeexponování investic („přehřátí ekonomiky“, tedy ze stejné chyby jako u pětiletky první). Na závěr jeho referátu pak zazněl podstatný poznatek, že komunistický režim si s krizí, která ostatně podle jím vyznávané ekonomické teorie vůbec neměla nastat, nevěděl prríliš rady a jeho reakce nebyla nijak rozhodnější či rychlejší než opatření, jež zkoušely v dobách krizí uplatňovat tržní ekonomiky.

Velmi přínosnou skupinu tvořily příspěvky zabývající se případovými studiemi (Jiří Fiala: Mladá česká banka v období deflační krize 19221923; Ivan Jakubec: Firma Schenker za velké hospodářské krize; Martin Minařík: Manažerskýsen. Expanze firmy $v$ době hospodárské krize. Př́klad Smíchovského pivovaru). Ivanem Jakubcem prezentovaná firma Schenker je príkladem firmy, které velká hospodářská krize 30 . let zlomila vaz. V dobách konjunktury první poválečné dekády prožívala firma raketový růst, expandovala na řadu světových trhů. $V$ závěru dvacátých let se však management rozhodl k velkým investičním akcím, kvůli nimž firmu neúměrně zadlužil. Když o rok později nastoupila hospodářská krize, toto zadlužení se stalo Schenkeru osudným. Př́spěvek Martina Minaříka vykreslil zcela odlišný příběh. Zabýval se podnikatelským úvěrem v oblasti pohostinství. V období první republiky bylo obvyklé, že pivovary půjčovaly peníze hostinským (nebo lidem, za které hostinští ručili, např. jejich prríbuzným), kteří nedosáhli na úvěr z bankovního sektoru. Protihodnotou úvěru byl závazek $\mathrm{k}$ odběru jejich piva. Jednalo se tedy o klasické uplatnění principu vítěz-vítěz (pro pivovary mimochodem výhodné dvojnásobně, protože úroky, za které peníze půjčovaly, byly vyšší než úroky bankovních půjček). Rozdíl mezi Smíchovským a ostatními (především plzeňskými) pivovary se projevil v době hospodářské krize 30. let minulého století. Zatímco ostatní podniky vsadily na konzervativní prístup a omezily, př́ípadně zcela zastavily poskytování úvěrů majitelům restaurací, smíchovští zvolili opačnou strategii a poskytování této služby ještě rozšíríili. A dobře udělali - ve třicátých letech byl Smíchovský akcionářský pivovar jediným z velkých českých producentů piva, který zaznamenal výrazný hospodářský růst. Př́spěvek tedy mírou vrchovatou potvrdil známé rčení, že krize s sebou vždy přináší také nové a výjimečné př́ležitosti.

$\mathrm{Z}$ desítky předneseným referátů zmiňme ještě kategorii komparačních př́spěvkủ (Miroslav Sabol: Kríza zásobovania - prídelový systém Protektorát Čechy a Morava verzus Slovenskýs stát; 
L'udovít Hallon: Paralely vývoja konjunkturálneho cyklu na Slovensku v medzivojnovom období a po roku 1993; Vít Pošta: Recese vyspělých ekonomikv 70. letech 20. stoletía v letech 2008-2009: Jak moc jsou odlišné). Závěrečný př́spěvek konference Krize na prahu 21. století přednesl prorektor VŠE prof. Jindřich Soukup. Zabýval se v něm především příčinami „překvapivosti“ aktuální hospodářské a finanční krize. Pokládal otázku, jak je možné, že téměř žádná relevantní instituce krizi nepředpověděla a pokud ano, byl předpokládán nástup krize pomalejší a její průběh podstatně mírnější, než jaká byla realita. Dospěl přitom $\mathrm{k}$ varujícímu závěru, že se mohlo jednat o vliv politické sféry, čímž nastínil další možný směr výzkumu.

Konference Fenomén hospodářské krize v českých zemích / střední Evropě 19. a 20. století se tedy v názvu uvedenému tématu věnovala velmi pečlivě a $\mathrm{z}$ nejrůznějších úhlů pohledu. Všem zájemcům o danou problematiku lze jednoznačně doporučit konferenční sborník, který by měl vyjít na počátku roku 2015.

\section{Jan Slavíček}

\section{Kolokvium „První světová válka v historicko-sociologické perspektivě“}

Kolokvium „První světová válka v historicko-sociologické perspektivě“, pořádané Sekcí historické sociologie při MČSS a Pracovištěm historické sociologie Fakulty humanitních studií Univerzity Karlovy v Praze, se konalo ve středu 29. ř́inna 2014. Ačkoliv je letošní rok tématem Velké války vysoce exponovaný, a to právě díky stoletému výročí jejího vypuknutí, a akademických konferencí, přednášek, článkủ, diskusí i výstav je na toto téma velké množství, povětšinou jsou doménou historiků. Zejména $\mathrm{z}$ tohoto důvodu bylo snahou organizátorů uspořádat koncepci kolokvia tak, aby byl poskytnut prostor především interdisciplinárně zaměřeným př́spěvkům, at už z oblasti historie, sociologie, filozofie, politologie, orientalistiky či demografie.

Úvodní prríspěvek přednesl profesor Johann Arnason. Stěžejní myšlenkou jeho příspěvku bylo vnímání první světové války jako civilizačního kolapsu evropské modernity, nebot válka udělala definitivní tečku za světovou hegemonií Evropy. Předválečná evropská modernita se vyznačovala multiimperiálním charakterem vzájemně soupeřících politických jednotek v podobě evropských států. Toto soupeření se však odehrávalo v prostoru společně sdílené kultury a za existence nadnárodními vazbami propojené a relativně unifikované evropské elity (podle profesora Arnasona tuto konstelaci připomínají také některá období historie islámského světa, v němž se vyprofilovaly vzájemně soupeřící Osmanská říše, Perská říše a Mughalská říše). Osmanskou rríši a carské Rusko, také zatažené do války, lze přitom chápat jako hraniční oblasti, jež do výše vymezeného evropského civilizačního prostoru patřily jen částečně. Profesor Arnason zároveň připomněl, že civilizační kolapsy jsou vesměs provázeny regeneracemi jakožto souvisejícím procesem, ve kterém některé civilizace zkolabovaly, ovšem následně se několikrát dokázaly zregenerovat (oblasti starověké Mezopotámie a Egypta). Výsledkem kolapsu předválečné evropské modernity byl pak vznik versailleského systému a tzv. krátkého 20. století (1918-1991), čímž došlo k diskreditaci evropského liberálního modelu moci, organizace společnosti a snahy formulovat vůči němu radiální alternativy $\mathrm{v}$ podobě alternativních modernit. Navazujícím tématem přednášky byla samotná prričina války. Přitom otázku, proč válka vypukla, by možná bylo přínosnější postavit opačně: proč se zhroutilo mírové uspořádání. Johann Arnason odpovídá, že válku nelze jednoduše vysvětlit v duchu marxismu jako důsledek fungování kapitalismu, který ve svém posledním imperiálním stadiu začal narážet na své limity. Tehdejší velmoci sledovaly koncentraci všech tři základních typů moci: bohatství, moc i prestiž (prosazení vlastní ideologie). Stejně tak je obtížné vyložit válku jako logický důsledek dynamiky formujících se aliancí a jejich vzájemné polarizace (typicky vykládat válku jako důsledek záměrné politiky centrálních mocností). V tomto procesu je totiž prrítomno príliš mnoho kontingence a nahodilosti. K válce nemuselo dojít, existovalo větší množství stejně pravděpodobných cest vývoje. Stejně tak nejsou zcela uspokojivé interpretace pracující se subjektivními faktory a motivacemi jednotlivých aktérů. Nikdo z aktérů neměl tak významné 